\title{
Impact of autologous hematopoetic stem cell transplantation on the quality of life of patients with multiple sclerosis
}

\author{
Fabio Augusto Bronzi Guimarães ${ }^{1}$, Érika Arantes de Oliveira-Cardoso², \\ Ana Paula Mastropietro ${ }^{3}$, Júlio César Voltarelli4, Manoel Antônio dos Santos ${ }^{5}$
}

\begin{abstract}
Objective: To evaluate the impact of autologous hematopoetic stem cell transplantation (autoHSCT) in the health related quality of life (HROL) in patients with multiple sclerosis. Method: The sample consisted of 34 patients, over 18 years old, treated at a University Hospital in the state of São Paulo, Brazil. For data collection MOS SF-36 and EDSS scales were applied at three time points: admission of the patient, hospital discharge and 1 year posttransplantation. Results: 27 patients (79\%) showed stabilization or neurological improvement 1 year posttransplantation. At this time point, there was statistically significant improvement in all domains of the HRQoL. When EDSS scores were correlated with the domains of the MOS SF-36 scale, statistically significant correlations were found with physical functioning at the three time points analysed. Conclusion: In spite of the high risk of complications of the procedure, the HSCT had positive impact in the health related quality of life.
\end{abstract}

Key words: quality of life, multiple sclerosis, bone marrow transplantation.

Impacto do transplante autólogo de células-tronco hematopoéticas na qualidade de vida de pacientes com esclerose múltipla

\section{RESUMO}

Objetivo: Avaliar o impacto do transplante de células-tronco hematopoéticas (TCTH) na qualidade de vida relacionada à saúde (OVRS) de pacientes com esclerose múltipla (EM). Método: A amostra foi composta por 34 sujeitos, maiores de 18 anos, atendidos em um hospital-escola do interior do Estado de São Paulo, Brasil. Para coleta de dados foram aplicados os instrumentos MOS SF-36 e EDSS. Resultados: 27 (79\%) sujeitos apresentaram estabilização ou melhora neurológica um ano após o TCTH. Decorrido um ano do procedimento, houve melhora estatisticamente significativa em todos os

\section{Correspondence}

Érika Arantes de Oliveira-Cardoso Departamento de Psicologia e Educação Faculdade de Filosofia, Ciências e Letras, Universidade de São Paulo Av. Bandeirantes 3900 14040-901 Ribeirão Preto SP - Brasil E-mail: erikaao@ffclrp.usp.br

\section{Support}

Financial support from Fundação de Amparo à Pesquisa do Estado de São Paulo-FAPESP, process $n^{\circ} 03 / 10921-4$

Received 4 November 2009 Received in final form 2 February 2010 Accepted 15 February 2010 domínios da QVRS. Ao relacionar os escores da EDSS com os domínios do MOS SF-36, foram encontradas diferenças estatisticamente significantes na Funcionalidade nos três momentos do TCTH. Conclusão: Apesar do elevado risco de complicações, pode-se afirmar que o TCTH repercutiu positivamente na apreciação que o paciente faz de sua OVRS. Palavras-chave: qualidade de vida, esclerose múltipla, transplante de medula óssea.

\footnotetext{
'Psychologist, M.Sc in Psychology, Post-graduation Program in Psychology of the Faculty of Philosophy, Sciences and Letters of Ribeirão Preto, University of São Paulo, Ribeirão Preto SP, Brazil (FMRP-USP); ${ }^{2}$ Psychologist, Bone Marrow Transplant Unit of the Clinical Hospital, School of Medicine of Ribeirão Preto, FMRP-USP. M.Sc, PhD in Psychology, Post-Graduation Program in Psychology of the Faculty of Philosophy, Sciences and Letters of Ribeirão Preto, University of São Paulo, Ribeirão Preto SP, Brazil (FFCLRP-USP); ${ }^{3}$ Occupational Therapist from the Occupational Therapy Service of the Clinical Hospital, School of Medicine of Ribeirão Preto, FMRP-USP. PhD in Psychology, Post-Graduation Program in Psychology, FFCLRP-USP; ${ }^{4} F u l l$ Professor, School of Medicine of Ribeirão Preto, FMRP-USP. Coordinator of the Bone Marrow Transplant Unit from the Clinical Hospital, School of Medicine of Ribeirão Preto, FMRP-USP; ${ }^{5} \mathrm{M}$.Sc and PhD in Clinical Psychology, Psychology Institute of the University of São Paulo. PhD, Professor from the Post-Graduation Program in Psychology, FFCLRP-USP.
} 
In addition to the physical complications to which the sufferer of multiple sclerosis (MS) is subject, the psychological aspects of this disease should also be considered. The incidence of psychopathological disorders, especially depression, is high in MS and may be even higher than in other neurological and chronic disabling diseases. The results of some international studies suggest that up to one third of MS patients may have symptoms of depression ${ }^{1}$. In the Brazilian context the prevalence of depressive symptoms in MS reaches $17.9 \%$ and anxiety symptoms, $35.7 \%$.

Another study in 104 patients with MS showed that depression has a negative impact in all domains of the health-related quality of life (HRQoL) and anxiety has negative impact in mental domains ${ }^{3}$. Other studies show that depressive symptoms in MS correlate with fatigue ${ }^{4-6}$.

Another variable which influences the HRQoL in MS patients is functional disability, which is measured by the EDSS scale. In the literature, it was observed positive correlation of depression and functional impairment and negative correlation between functional impairment and HRQoL domains measured by the MOS SF-36 scale 7 .

Advances in pharmacobiological therapy for systemic autoimmune diseases (AID) have not prevented a subpopulation of patients with progressive forms of these diseases, refractory to conventional therapy, having a poor prognosis. The low life quality and life expectancy of these patients justifies the use of very aggressive therapies such as high dose chemotherapy, immunotherapy and/or radiotherapy, with or without hematopoetic stem cell transplantation (HSCT) ${ }^{8}$.

HSCT is essentially the replacement of defective bone marrow with a healthy and efficacious one ${ }^{9}$. There are currently various types of HSCT, the differentiator being the source of the progenitor cells. Autologous HSCT, the object of this study, is characterized by the fact that the donor is the patient himself, who has his cells extracted during the process of remission of the disease.

Autologous HSCT appears in this scenario as a promising alternative treatment for MS. It was initially proposed as a treatment for this disease in the nineties ${ }^{10}$. Studies showed that there was a halt in the progress of the disease after three years in about $75 \%$ of cases of MS patients who underwent autologous HSCT ${ }^{11}$.

However, despite the initial encouraging results, it should be noted that HSCT is not a procedure that yields full resolution. The immunosuppression induced by the preHSCT conditioning makes the patient temporarily vulnerable to many complications which impair his/her physical well being and threaten his/her life ${ }^{8}$.

Because it is an innovative therapy in the treatment of AID, there is an urgent need for studies that can assess not only the effectiveness of the technique, but also its impact on patients' lives. Most studies have been lim- ited to the clinical approach, despite the wide recognition of the importance of also evaluating the emotional aspects involved when this therapy is used to treat diseases such as MS.

The assessment of the quality of life construct allows an analysis to be made, from the perspective of the patient, of the impact of a disease and of the proposed treatments. In this context, quality of life constitutes an important indicator of the ability of a chronic autoimmune disease, such as MS, to significantly affect the patient's welfare ${ }^{12}$.

As the present study is within a biomedical field, the concept of health-related quality of life was used, which can be understood as the perceived health status. This refers to the perception of a person, with or without a disease, in relation to their state of health ${ }^{13-14}$.

Among the instruments used to assess HRQoL, the generic ones are those developed in order to reflect the impact of a disease on the lives of patients in a wide variety of populations ${ }^{15}$. Medical Outcomes Study 36-Item Short-Form Health Survey (MOS SF-36) is one of the most used questionnaires, in a health context, throughout the world.

A study of HRQoL compared the performance obtained by patients with MS in relation to the normative population and demonstrated an overall negative impact caused by the disease in all evaluated domains ${ }^{16}$. In the Brazilian context, the study compared HRQoL in MS patients with a healthy population and confirmed the hypothesis that the patients have impaired HRQoL in physical and psychosocial domains, in relation to the healthy population ${ }^{17}$.

On study performed in Brazil ${ }^{18}$ showed that autoimmune diseases by themselves lead to an intense decrease of HRQoL in patients submitted to HSCT for those diseases. In that study, pretransplant and early postransplant results were compared in 19 patients submitted to HSCT. The evaluation indicated an improvement in the domain of physical functioning of HRQoL assessed by the MOS SF-36 scale. The improvement of some aspects of the HRQoL after transplantation, compared to the pretransplant period, was observed both in the national and international literature ${ }^{19-20}$.

According to the literature, the variables that may influence the HRQoL in patients with MS submitted to HSCT are general mental health (anxiety and depression disorders), vitality (fatigue, tiredness, exaustion), the EDSS score and the time from diagnosis to the procedure.

This study aims to contribute to this field of research, since, in both national and international literature, there are few studies on the quality of life of MS patients undergoing HSCT therapy, due to its high complexity and pioneering status.

The goal of the study was to evaluate the impact of the HSCT in the HRQoL of MS patients. Specifically, it 
evaluated the relationship between the dependent variables time, EDSS score and HRQoL domains in MS patients submitted to HSCT.

\section{METHOD}

This is a descriptive, exploratory and clinical study, with longitudinal cross-section. The project was approved by the Ethics Committee of the Clinical Hospital, School of Medicine of Ribeirão Preto, University of São Paulo (HCFMRP No 5808/2007).

\section{Patients}

The sample consisted of 34 patients with MS, of both sexes, who had undergone autologous HSCT in the Bone Marrow Transplant Unit (BMTU) - HCFMRP-USP, between May 2003 and May 2008. The sample represents $85 \%$ of the study population. The selection criteria included having MS diagnosis; having a minimum age of 18 years; being attended on the ward and at the outpatient clinic of the BMTU during the period defined by the evaluation; presenting medical and psychological conditions; being willing to cooperate voluntarily with the research.

\section{Instruments}

[1] The Medical Outcomes Study 36-Item Short-Form Health Survey (MOS SF-36 Health Survey) ${ }^{21}$ is a measure of health status designed for use in clinical practice, research, health policy evaluations, and general population surveys. It is a multidimensional instrument for generic assessment of HRQoL, originally created in the English language, translated and validated for Brasil ${ }^{22}$. It consists of 36 items that assess two components: the physical health component (PHC) and the mental health component (MHC). The PHC comprises the domains: physical functioning, role limitations due to physical problems, bodily pain and general health perceptions. The MHC comprises the domains: vitality, social functioning, role limitations due to emotional problems and general mental health. The results of each domain range from 0 to 100 , in which zero represents the worst state of health and 100 the best state of health ${ }^{22}$.

[2] Expanded Disability Status Scale (EDSS) ${ }^{23}$ : is a scale employed to determine functional performance in MS, translated and validated for the Portuguese language $^{24}$. The scale is used as a main measurement of efficacy in most clinical studies of MS, albeit it overemphasizes mobility and is less sensitive to other dimensions of the disease ${ }^{25}$. EDSS values are directly proportional to the patient's neurological dysfunction.

\section{HRQoL evaluation}

Data were collected at the three critical points proposed for evaluation patient admission, hospital discharge and 1 year after transplantation. The instruments were applied individually in a closed environment, considering the principles of comfort and privacy of the subjects of the study.

The job of scoring the MOS SF-36 data was carried out by two judges, both psychologists with expertise in psychological assessment, one of them being the researcher. They independently established the results and classified the protocols. The judges operated according to specific recommendations from the literature for correction of each instrument.

With the scored protocols, the data was tabulated using the database program Excel for Windows 2007 ver-

Table 1. Numerical and percentage distribution of patients with multiple sclerosis undergoing stem cell transplantation, according to socio-demographic and clinical characteristics $(n=34)$. Ribeirão Preto, Brazil, 2003-2008.

\begin{tabular}{|c|c|c|}
\hline Socio-demographic and clinical variables & $\mathrm{N}$ & $\%$ \\
\hline \multicolumn{3}{|l|}{ Sex } \\
\hline Female & 18 & 52.9 \\
\hline \multicolumn{3}{|l|}{ Age group (years) } \\
\hline$\leq 25$ & 2 & 5.9 \\
\hline 26 a 35 & 7 & 20.6 \\
\hline 36 a 45 & 16 & 47.1 \\
\hline$\geq 46$ & 9 & 26.4 \\
\hline \multicolumn{3}{|l|}{ Conjugal status } \\
\hline Without partner & 13 & 38.2 \\
\hline With partner & 21 & 61.8 \\
\hline \multicolumn{3}{|l|}{ Education (years) } \\
\hline 1 a 4 & 5 & 14.7 \\
\hline 5 a 11 & 15 & 44.1 \\
\hline$\geq 12$ & 14 & 41.2 \\
\hline \multicolumn{3}{|l|}{ Occupational situation } \\
\hline Inactive & 28 & 82.3 \\
\hline Active & 6 & 17.7 \\
\hline \multicolumn{3}{|l|}{ Household income (minimum wages) } \\
\hline$<3$ & 7 & 20.6 \\
\hline 3 a 5 & 14 & 41.2 \\
\hline$>5$ & 13 & 38.2 \\
\hline \multicolumn{3}{|l|}{ Religion } \\
\hline Practicing & 23 & 67.7 \\
\hline Non-practicing & 11 & 32.4 \\
\hline \multicolumn{3}{|l|}{ Length of diagnostic (years) } \\
\hline$\leq 5$ & 8 & 23.5 \\
\hline 6 a 7 & 13 & 38.3 \\
\hline 8 a 10 & 8 & 23.5 \\
\hline$\geq 11$ & 5 & 14.7 \\
\hline \multicolumn{3}{|l|}{ Clinical form of MS* } \\
\hline RRMS & 7 & 20.6 \\
\hline PPMS & 5 & 14.7 \\
\hline SPMS & 22 & 64.7 \\
\hline
\end{tabular}

*The clinical forms of MS: RRMS-relapsing remitting multiple sclerosis, PPMS primary progressive multiple sclerosis, SPMS-secondary progressive multiple sclerosis. 
sion. To achieve the objective of the study, a statistical analysis was used to evaluate the relationship of dependent variables (time of HSCT, EDSS score, vitality, general mental health, physical functioning) and independent variables (other domains of HRQoL evaluated by the MOS SF-36 scale). In order to evaluate the difference between the results obtained in the 3 time points of the study, the nonparametric Friedman test for multiple comparison was used. To evaluate the correlations between dependent and independ variables, the nonparametric Spearman correlation test was used. Significance levels used were $\mathrm{p} \leq 0.05$ e $\mathrm{p} \leq 0.01$.

\section{RESULTS}

Table 1 displays the social-demographic and clinical profile of the patients included in the study.

In Table 2 the results of the MOS SF-36 scores for HRQoL are shown in three periods (preHSCT, postHSCT1 and postHSCT2).

Comparing the three time points, it is observed an EDSS stabilization in 16 patients (47\%), reduction of EDSS values in 11 (32\%) and increase of EDSS in 5 (15\%); in two patients (6\%), there was progression of neurolog- ic disability in the $2^{\text {nd }}$ time point followed by improvement in the $3^{\text {rd }}$ time point. In summary, in 27 out of 34 patients (79\%), EDSS score estabilized or reduced 1 year after transplantation.

Table 3 shows the correlations between EDSS values and the MOS SF-36 domains.

\section{DISCUSSION}

In relation to the clinical forms of the disease, a prevalence of progressive forms could be seen, $80.4 \%$ in total, with $64.7 \%$ of patients diagnosed with the secondary progressive form (SPMS). Relapsing remitting MS (RRMS) appeared in $20.6 \%$ of patients who comprised the sample. This result is in disagreement with the results of epidemiological studies and the clinical characterization of MS in the Brazilian context, which demonstrate a prevalence of RRMS $^{26-28}$. This finding suggests that patients with more severe forms of MS are more likely and motivated to accept treatment as complex and impacting as HSCT.

Patients with long-term MS who have lived for many years with the disease have suffered sharp depreciations in their HRQoL as a result of disease progression and have tried various treatments without obtaining satisfactory re-

Table 2. Comparison between time of HSCT and the MOS SF-36 domains ( $n=34)$, Ribeirão Preto, Brazil, $2003-2008$.

\begin{tabular}{lccc}
\hline & PreHSCT $\times$ PostHSCT1 & PreHSCT1 $\times$ PostHSCT2 & $\begin{array}{c}\text { Post HSCT1 } \times \text { PostHSCT2 } \\
\text { Mos SF-36 Domains }\end{array}$ \\
\hline Physical functioning & 0.09 & $<$ & $<0.01$ \\
Role limitations due to physical problems & 0.76 & $<0.01$ & $<0.01$ \\
Bodily Pain & 0.50 & $<0.01$ & $<0.01$ \\
General health perceptions & 0.12 & $<0.01$ & $<0.01$ \\
Vitality & 0.28 & $<0.01$ & $<0.01$ \\
Social functioning & 0.99 & $<0.01$ & $<0.01$ \\
Role limitations due to emotional problems & 0.86 & 0.01 & 0.01 \\
General mental health & 0.48 & $<0.01$ & $<0.01$ \\
\hline
\end{tabular}

HSCT: hematopoietic stem cell transplantation.

Table 3. Correlations between EDSS values and the MOS SF-36 domains ( $n=34)$, Brazil, Ribeirão Preto, 2003-2008.

\begin{tabular}{|c|c|c|c|c|c|c|}
\hline \multirow[b]{2}{*}{ MOS SF-36 Domains } & \multicolumn{2}{|c|}{ preHSCT EDSS } & \multicolumn{2}{|c|}{ post HSCT1 EDSS } & \multicolumn{2}{|c|}{ post HSCT2 EDSS } \\
\hline & $p$ & $r$ & $\mathrm{p}$ & $r$ & $\mathrm{p}$ & $r$ \\
\hline Physical functioning & $0.002^{*}$ & -0.509 & $<0.001^{*}$ & -0.667 & $0.001^{*}$ & -0.534 \\
\hline Role limitations due to physical problems & 0.464 & 0.130 & 0.344 & -0.167 & 0.594 & -0.095 \\
\hline Bodily pain & 0.438 & -0.137 & 0.288 & -0.187 & 0.066 & -0.318 \\
\hline General health perceptions & 0.893 & -0.24 & 0.314 & -0.178 & 0.091 & -0.294 \\
\hline Vitality & 0.815 & 0.042 & 0.621 & 0.008 & 0.717 & -0.065 \\
\hline Social functioning & 0.732 & -0.061 & 0.525 & -0.113 & 0.187 & -0.232 \\
\hline Role limitations due to emotional problems & 0.686 & -0.072 & 0.353 & -0.164 & 0.518 & -0.115 \\
\hline General mental health & 0.493 & 0.122 & 0.697 & -0.069 & 0.746 & 0.058 \\
\hline
\end{tabular}

${ }^{*} p \leq 01$ 
sults. Probably, these patients are tired of living with limitations, such as changes in vision, loss of balance, tremors, weakness, changes in the rhythm of speech, memory loss, among others. This makes them more motivated to undergo a radical treatment such as HSCT. Transplantation offers the possibility of a recovery of quality of life which is already highly compromised. This finding corroborates the results of other studies ${ }^{29-30}$.

In the MOS SF-36 evaluation, it is observed a significant improvement in all HRQoL domains 1 year after transplantation (period postHSCT2) but not after hospital discharge (postHSCT1).

In another Brazilian study ${ }^{18}$ comparing the results of the domains of HRQoL assessed by MOS SF-36, in patients with autoimmune diseases who received HSCT treatment, no significant differences between the preHSCT and post-HSCT period (30 days after the procedure) was shown. However, the authors pointed out that the patients demonstrated perception of improvement in some aspects of their HRQoL, suggesting the importance of research using a qualitative approach to identify subtle differences in the self-assessment of patients.

The perception of improvement of HRQoL in the late posttransplantation period may be related to the fact that the patients may not face the constant possibility of disease progression, translated by stabilization or improvement of neurologic function 1 year after the procedure. This result may be interpreted as a positive outcome of the HSCT for MS, measured by the evolution of the EDSS score.

Another finding of our study is a negative correlation between the EDSS score and the score of physical functioning of the MOS SF-36 scale in the three time points. This result agrees with data from the literature showing that the functional capacity estimated by the EDSS score influences the HRQoL of patients with MS ${ }^{31-33}$.

To the extent that this stressor, so characteristic of patients with MS, is alleviated and limited by HSCT treatment, the possibility emerges to rethink work and family issues, and also to recapture some of the dreams and undertake projects that had been put aside. This shows that patients feel more excited about the chance to be able to reorganize their lives and reintegrate into society ${ }^{18}$.

One factor that must be considered when referring to the HRQoL of patients with MS, especially in its more severe forms, undergoing HSCT, is the change imposed on the way they live life. Patients recover HRQoL they had before the procedure, but not the quality of the same life. Perception of changes, such as greater appreciation of life, resignification of values and the seeking of closer and more satisfactory relationships being common ${ }^{33}$. Thus, from the patients' perspective, the changes imposed by the transplantation procedure not always have negative meaning.

When affected by a progressive and disabling disease like MS, patients feel that they have lost control of their destiny. HSCT brings relief and restores the hope of, once again, having their lives in their hands. Despite all the complications and the impact caused by this therapy, it could be argued that it reflects positively on the appreciation patients' have for their HRQoL.

\section{REFERENCES}

1. Haase VG, Lacerda SS, Lima EP, Corrêa TD, Brito DCS, Peixoto MAL. Avaliação do funcionamento psicossocial na esclerose múltipla. Arq Neuropsiquiatr 2004;62:282-1291

2. Mendes MF, Tilbery CP, Balsimelli S, Moreira MA, Cruz AMB. Depressão na esclerose múltipla forma remitente-recorrente. Arq Neuropsiquiatr 2003;61: 591-595.

3. Goretti B, Portaccio E, Zipoli V, et al. Coping strategies, psychological variables and their relationship with quality of life in multiple sclerosis. Neurol Sci 2009;30:15-20.

4. Flachenecker P, Kumpfel T, Kallmann B, Gottschalk M, Grauer O, Rieckmann P. Fatigue in multiple sclerosis: a comparison of different rating scales and correlation to clinical parameters. Multiple Sclerosis 2002;8:523-526.

5. Pittion-Vouyovitch S, Debouverie M, Guillemin F, Vandenberghe N, Anxionnat $R$, Vespignani $H$. Fatigue in multiple sclerosis is related to disability, depression and quality of life. J Neurol Sci 2006;243:39-45.

6. Kale N, Agaoglu J, Tanik O. Neuropsychiatric manifestations in multiple sclerosis: correlation of fatigue and depression with disease progression. Neurol Res 2009; Aug 5.

7. Pakpour AH, Yekaninejad MS, Mohammadi NK et al. Health-related quality of life in Iranian patients with multiple sclerosis: a cross-cultural study. Neurol Neurochir Pol 2009;43:517-526.

8. Voltarelli JC, Stracieri ABPL, Oliveira MCB, et al. Transplante de células-tronco hematopoéticas em doenças reumáticas parte 1: experiência internacional. Rev Bras Reumatol 2005;45:229-241.

9. Peres RS, Santos MA. A exclusão de afeto e a alienação do corpo. São Paulo: Vetor, 2006.

10. Fassas A, Anagnostopoulos A, Kasis A. Peripheral blood stem cell transplantation in the treatment of progressive multiple sclerosis: first results of a pilot trial. Bone Marrow Transplant 1997;20:631-638.

11. Saccardi R, Mancardi GL, Solari A, et al. Autologous HSTC for severe progressive multiple sclerosis in multicenter trial impact on disease activity and quality of life. Blood 2005;105:2601-2607.

12. Miller A, Dishon S. Health-related quality of life in multiple sclerosis: the impacto of disability, gender and employment status. Qual Life Res 2006;15: 259-271.

13. Fayers PM, Machini D. Quality of life: the assessment, analysis and interpretation of patient-reported outcomes. 2nd Ed. Chichester: John Wiley \& Sons. 2007:3-30.

14. Ashing-Giwa KT. The conceptual model of HRQoL: a paradigm for expanding the HRQoL framework. Qual Life Res 2005;14:294-307.

15. Ciconelli RM. Medidas de avaliação de qualidade de vida. Rev Bras Reumatol 2003:43:9-13.

16. Solari A. Role of heath-related quality of life measures in routine care of people with multiple sclerosis. Health Qual Life Outcomes 2005;3:16-19.

17. Morales RR, Morales NMO, Rocha FCG, Fenelon SB, Pinto RMC, Silva CHM. Qualidade de vida em portadores de esclerose múltipla. Arq Neuropsiquiatr 2007;65:454-460.

18. Guimarães FAB, Santos MA, Oliveira EA. Qualidade de vida de pacientes com doenças auto-imunes submetidos ao transplante de medula óssea: um estudo longitudinal. Rev Lat Am Enfermagem 2008;6:856-863.

19. Claessens JJM, Beerendonkand CCM, Schattenberg AVMB. Quality of life, reproduction and sexuality after stem cell transplantation with partially T-celldepleted grafts and after conditioning with a regimen including total body irradiation. Bone Marrow Transplant 2006;37:831-836.

20. Mastropietro AP, Oliveira EA, Santos MA, Voltarelli JC. Functional assessment of cancer therapy bone marrow transplantation: tradução e validação. Rev Saúde Pública 2007:41:260-268.

21. Ware Jr JE, Sherbourne CD. The MOS 36-Item Short-Form Health Survey (SF36): conceptual framework and item selection. Med Care 1992;30:473-481.

22. Ciconelli RM, Ferraz MB, Santos W, Meinão I, Quaresma MR. Tradução para a língua portuguesa e validação do questionário genérico de qualidade de vida SF-36. Rev Bras Reumatol 1999;39:143-150. 
23. Kurtzke JF. Rating neurologic impairment in multiple sclerosis: an expanded disability status scale (EDSS). Neurology 1983;33:1444-1452.

24. Mendes MF, Balsimelli S, Stangehaus G, Tilbery CP. Validação de escala de determinação funcional da qualidade de vida na esclerose múltipla para a língua portuguesa. Arq Neuropsiquiatr 2004;62:108-113.

25. Canadian Burden of Illness Study Group. Burden of illness of multiple sclerosis. II. Quality of life. Can J Neurol Sci 1998;25:31-38.

26. Fragoso YD, Fiore APP. Description and characteristics of 81 patients attending the reference center for multiple sclerosis of the coastal region of the State of Sao Paulo-Brazil. Arq Neuropsiquiatr 2005;63:741-744.

27. Ferreira MLB, Machado MI, Vilela ML. Epidemiologia de 118 casos de esclerose múltipla com seguimento de 15 anos no centro de referência do Hospital da Restauração de Pernambuco. Arq Neuropsiquiatr 2004;62:1027-1032.

28. Arruda WO, Scola RH, Teive HAG, Werneck LC. Multiple sclerosis: report on 200 cases from Curitiba, Southern Brazil and comparison with other Brazilian series. Arq Neuropsiquiatr 2001;59:165-170
29. Oliveira EA, Santos MA, Mastropietro AP. Oficinas terapêuticas: uma possibilidade de intervenção em saúde mental. In: CP Simon, LL Melo-Silva, MA Santos (Orgs), Formação em psicologia: desafios da diversidade na pesquisa e na prática. São Paulo: Vetor 2005:365-378.

30. Muller M, Carvalho EC, Canini SRMS. Fontes de esperança para pacientes submetidos ao transplante de células tronco hematopoiéticas. Rev de Enferm UFPE 2008;2:292-296.

31. Jongen PJ, Sindic C, Carton H, Zwanikken C, Lemmens W, Borm G. Improvement of health-related quality of life in relapsing remitting multiple sclerosis patients after 2 years of treatment with intramuscular interferon-beta-1a. J Neurol 2009 Nov 18.

32. Ghaem $\mathrm{H}$, Haghighi AB. The impact of disability, fatigue and sleep quality on the quality of life in multiple sclerosis. Ann Indian Acad Neurol 2008; 11:236-241.

33. Broers S, Kaptein A, Cessie S, Fibbe W, Hengeveld MW. Psychological functioning and quality of life foloowing bone marrow transplantation: a 3-year follow-up study. J Psychosom Res 2000;48:11-21. 